\title{
Occasional photographic records of butterflies (Lepidoptera, Hesperioidea and Papilionoidea) in Cambodia. 2. Ratanakiri and Mondulkiri Provinces of Eastern Cambodia, 2013-2018.
}

\author{
O. E. Kosterin \\ Institute of Cytology \& Genetics, Siberian Branch Russian Academy of Science \\ Acad. Lavrentyev Av. 10, Novosibirsk, 630090, Russia \\ Novosibirsk State University \\ Pirogova St. 2, Novosibirsk, 630090, Russia \\ E-mail:kosterin@bionet.nsc.ru
}

\begin{abstract}
In this article I present the casual photographic records of butterflies (Lepidoptera, Papilionoidea) made along with the studies on the Odonata fauna in 33 localities of two eastern provinces of Cambodia, Ratanakiri and Mondilkiri in 2013-2018. The butterflies were photographed in purely natural conditions without any restriction of their freedom and mobility, using two cameras, Olympus Camedia C8080 and Canon EOS 350D, the latter with the lens Sigma AF 24-70 mm F2.8 EX DG MACRO. Coordinates were obtained with Garmine eTrex H personal GPS navigator and revised with Google Earth; elevations were retrieved from Google Earth. In total, I identified 118 and provisionally identified five species; 19 species (Abisara cf. bifasciata, Poritia cf. hewitsoni, Ahmetia achaja, Arhopala nicevillei, Sinthusa chandrana, Virachola sp. cf. kessuma, Zizeera maha, Tirumala limniace, Junonia hierta, Yoma sabina, Terinos clarissa, Euripus nyctelius, Lethe rohria, Bibasis sena, Caprona agama, C. alida, Aeromachus cf. pygmaeus, Gangara thyrsis, and Udaspes folus) and one subspecies (Kallima inachus alboinachus) are reported for Cambodia for the first time. I also illustrated these species as well as some more provisionally identified and unidentified for this region.
\end{abstract}

Key words: butterflies; Cambodia; Indochina; Diurna; Rhopalocera; Papilionoidea; unidentified species; Ratanakiri; Mondulkiri

\section{Introduction}

Butterflies are among few insects beloved by public and at the same time used as explicit indicators of habitat quality. Some half a century ago, Cambodia was a bewildered kingdom of vast areas of pristine tropical forests, but now it is among the most rapidly deforested countries. Notably these are mostly lowland tropical forests, persisting in the country until present, which are being especially furiously logged (Kosterin 2019a; 2019b). In view of this rampant loss of biodiversity, it is especially dramatic that Cambodia has yet been so scarcely studied with respect to biodiversity. Even the butterfly fauna, which is usually among the best known, is still poorly revealed so that it is easy to meet a species not yet reported for the country. In recent decades just five papers devoted to them were published: two with results of the butterfly-focused trips by Hiraoki Onodera $(2007 ;$ 2008; 2009a), one with results of a thorough stationary study of the Phom Samkos Wildlife Sanctuary in the inland Cardamoms by Monastyrskii et al. (2011), a popular atlas of the butterflies of SW Cambodia by Woodfield and Murton (2006). Among them also was the initial communication by Kosterin (2019a) based on photographic records only; and the current paper is the second from this series. The checklist of Cambodian butterflies has not been published yet. Yutaka Inayoshi (2019) summarised the faunistic information on butterflies of Thailand and Indochina at his most popular and quite comprehensive internet site 'A Check List of Butterflies in Indo-China'. However, the data on Cambodia are only partially presented there since many species reported by Monastyrskii et al. (2011) are still missing. In view of this paucity of data on the background of habitat loss, even preliminary knowledge of butterfly fauna and distribution in Cambodia becomes useful. Because of their wing pattern, many butterflies can be reliably identified by photographs. Nevertheless, identification of quite a number of butterflies require examination of the male genitalia or demand the pattern of both wing sides, that is rarely available in photos. Most of species in the genera Melanitis Fabricius, 1807, Mycalesis Hübner, [1819], Ypthima Hübner, [1819], Potanthus Scudder, 1872 can hardly or not at all be identified by the wing pattern, while identification of many species in the genera Arhopala Boisduval, 1832, Jamides Hübner, [1819], 
Nacaduba Moore, [1881], Prosotas Druce, 1891 and of many genera in the family Hesperiidae is problematic. Nevertheless, publication of even preliminary faunal data, with explicit awareness of the limitations of the photographic method, is useful as a step of revealing the butterfly fauna of certain territory.

My 12 trips to Cambodia since 2006 (counting 178 days in total) were aimed at faunistic and taxonomic studies of dragonflies and damselflies (Odonata). Since I occasionally and rather non-selectively take pictures of butterflies while searching for odonates, a considerable by-side product of butterfly photographs is being accumulated and presented in my website (Kosterin 2019c). Earlier I summarised these data obtained from 2010 to 2018 in four south-western provinces of Cambodia occupying the coastal foothills of the Cardamom Mts. (Kosterin 2019a).

In this second communication, I present the photographic faunal data on butterflies obtained in the two eastern provinces residing in the western outskirts and Central Plateau of the Annamense Mountains: Ratanakiri, visited in 2013, and Mondulkiri, visited in 2014, 2016 and 2018. It is noteworthy that both provinces were earlier visited by H. Onodera, who collected butterflies in 2006 at Veun Sai, Poy, Kalay, Ban Lung, O'Chum, and Ta Veang in Ratanakiri Province (Onodera 2007) (the three latter sites also examined by me in 2013), and at Leu, Ou Play, Romonea, O'Rang, Sen Monorom, and Buu Sraa (Onodera 2009a) (again, the three latter sites examined by me in 2014-2018).

I also have some data from the western, north-western, and northern provinces of Cambodia, namely Pursat, Siem Reap, Preah Vihear, and Stung Treng, which will be published when I finish my preliminary odonatological investigations of these regions.

\section{Materials and methods}

\section{Methods}

The butterflies were photographed in purely natural conditions without any restriction of their freedom and mobility, using two cameras, Olympus Camedia C8080 and Canon EOS 350D, the latter with the lens Sigma AF 24-70 mm F2.8 EX DG MACRO. Coordinates were obtained with Garmine eTrex H personal GPS navigator and revised with Google Earth; elevations were retrieved from Google Earth.

\section{Identification and taxonomy}

The taxonomic system used in the site 'A Check List of Butterflies in Indo-China' (Inayoshi 2019) is adopted, but more subfamilies are recognised.

The butterflies were identified using the internet site 'Butterflies in Indochina' by Y. Inayoshi (2019) and some more taxonomically (Corbet 1941; Evans 1957; Nakamura 2014) or geographically restricted sources devoted to the butterflies of Thailand (Ek-Amnuay 2006, with corrigenda by Ek-Amnuay et al. 2007), Cambodia (Onodera 2009; 2008; 2009a), Laos (Onodera, 2009b, 2015 and his unpublished reports kindly provided by the author), Vietnam (Callaghan 2009) and Borneo (Seki et al. 2991). Useful hints came from the internet resources 'The Thailand Butterflies Species Gallery' by Antonio Giudici (2019) and illustrated checklists for Papilionoidea (Chartier, 2019a) and Hesperioideae (Chartier 2019b) of the Tatai Commune of Koh Kong Province of Cambodia at the internet site 'Gee's Nature Tours' by Gerard Chartier, who also greatly helped with identification of some difficult cases.

Most of the photos were identified to species. Provisional identifications are marked with 'cf'. With only two exceptions indicated below, no subspecies identification was attempted. However, most of the Oriental butterflies have geographically distinct subspecies so the species were formally attributed to their biogeographically relevant subspecies according to Inayoshi (2019).

All the photos are available at my internet site (Kosterin 2019c) and are open to be critically reconsidered.

\section{Abbreviations and designations}

The following widespread moprhological abbreviations were used: FW and HW - fore and hind wing, respectively, UPS and UNS - upperside and underside of both wings, respectively, UPF, UPH, UNF and UNH - upperside of fore and hind wing and underside of fore and hind wing, respectively; the numeration of spaces follows the standard British system in which they are numberred according to the dorsal (lower in the common illustration position) bordering vein (see Ek-Amnuay 2006). The Ratanakiri and Mondulkiri Provinces are abbreviated with two boldface letters Ra and Mo, respectively. The dates are given in the dd.mm.year system.

\section{The area}

\section{Ratanakiri Province}

Ratanakiri (Khmer 'Gem Mountains') Province, occupying the north easternmost part of Cambodia, is situated in the western side of the Annamense Mits. and so possesses considerable, up to 1,500 $\mathrm{m}$ a.s.l. and hardly accessible mountains in the north at the Lao and Vietnam borders, of which I could see only the very low (240 m a.s.l.) foothills.

The core of the province is a very gentle dome-like elevation formed by almost flat basalt rocks, with the capitol Ban Lung in its center. Its smoothly rolling hills have been nearly completely deforested and occupied by vast rubber (mostly south of Ban Lung) or cashew (mostly north of Ban Lung) plantations, leaving no room for any other tree and allowing very scarce grass on generally barren dark-red ground. Some patches of Gewea trees are old and looking like a loose forest; they are presently logged and replaced by young saplings, so the land for a long time has been undergoing plantation 
turnover. Only scarce tops of the most considerable (but actually very low) hills are occupied by tiny forest remnants, often just being logged when I saw them in 2013. Waterfalls are another reason for the locals to leave poor forest remnants in this area. Forest strips are as a rule left between the course of a river with a waterfall and plantations, although sometimes they are just a few trees wide. Only O'Sieng Lei waterfalls were surrounded by a considerable (ca $9 \times 5 \mathrm{~km})$ area of forest, although substantially disturbed. A semi-evergreen type, with Dipterocarpus alatus Roxb, mostly represents the forests in Ratanakiri Province are predominating, maybe together with some similar species. This forest type is somewhat open so that huge trees are well seen even from inside the forest. Among them, sparse tall but small-leaved bamboo and rattan palms are recognised in the canopy.

The remarkable crater Lake Yak Lom is perfectly round (750 x $720 \mathrm{~m}$ ), and said to be up to $48 \mathrm{~m}$ deep and to have been formed 700 thousand years ago. Its banks and the crater inner slopes, formed by large basalt plates, are overgrown with tall dipterocarp forest and bamboo thickets.

The Virachey National Park, occupying the north-easternmost mountainous part of the province and country is bordered from the south by one of the major Cambodian rivers, Se San or Tonle San River, which is broad and has barren clayey bluffs and banks. Its level strongly depends on the dam upstream in Vietnam. One of the main site inhabited there, Yorn village (Phum Yorn), is situated on the medium-sized O'Tabok River and is inhabited by the Brau minority; there first patches of the retained forest appeared. The area deeper into the 'National Park' was mostly logged semi-evergreen dipterocarp forest, with sparse tall trees left but generally replaced by bamboo thickets, with small brooks at the time of observation being chains of pools. A very specific type of habitats are 'veals', patches of fine grassy savannah formed by open stand of low trees, mostly Dipterocarpus obtusifolius Tejism. ex Miq., on a flat rocky basis. One of them was situated on the flat surface of Kong Kreav hill being the farest point of my examination. There we saw wild buffalo pitfalls at a small pool.

\section{Mondulkiri Province}

Mondulkiri Province (literally 'the Mountain of Mandala'), the largest in Cambodia $\left(14,288 \mathrm{~km}^{2}\right)$, is situated in the east of the country and occupies the western part and slopes of the Central Plateau of the Annamense Mts. Its western outskirts are covered with a large (ca $35 \times 20 \mathrm{~km}$ ) and still nearly undisturbed evergreen Seima Protected Forest (in fact protected only from logging, and maybe not for long) occupying gentle ridges at 150-600 $\mathrm{m}$ a.s.l. The latter elevation seems to be a limit of dense evergreen forest in this area. The plateau, where the province capitol Sen Monorom is situated, is mostly $s$ elevated to 600-850 $\mathrm{m}$ a.s.l. It is covered with grassy savannah with open tree stand and patches of evergreen forest in valleys of brooks and rivulets. It has a warm but not hot montane climate round the year. The area is still thinly populated (4.3 persons/ km² over the province) and not so much disturbed. The most conspicuous disturbance there is presence of large pine plantations. There is a forested Phnom Nimlyr Mt., 935 (or 982) m a.s.I. at the Vietnamese border, which I did not explore, yet it is only about $100 \mathrm{~m}$ higher than the plateau at Dak Dam village, inhabited by the Pnong (Bunong) minority, which I studied quite thoroughly. One can see in Google Earth that any forest disappear behind the Vietnamese border, hence the Cambodian territory is still a refuge of the peculiar nature of this area.

The area to the north-east of Sen Monorom, where the highest in Cambodia Buu Sraa Waterfall is situated, is somewhat less elevated (400-600 $\mathrm{m}$ a.s.l.) and more flat, although still resting on volcanic plates. It was, and partly still is covered with deciduous dry dipterocarp forests, obviously being in the rain shadow of the Plateau; nevertheless the river valley below the waterfall is clad with evergreen forest. This area is more populated and largely converted to farmland. It is crossed by three large rivers. A new good road has been recently constructed from Sen Monorom to Ban Lung, Ratanakiri. For 16 km NNE of Sen Monorom it goes through scarcely disturbed and well forested plateau and then descend to lowland almost completely turned into rubber plantations for quite a distance.

\section{List of localities}

The coordinates are given in decimal degrees. Usually their range for the area actually studied in each locality is indicated (after the decimal point). The elevations above the sea level are followed with ' $m$ '. The locality data are provided in the geographical order. To avoid confusion of numerals, localities are also denoted by conventional nicknames used in this series of papers. They partly coince with nicknames given and used in my odonatological publications, which are enclosed in single quotations (Kosterin 2014; 2016). These nicknames follow the locality ordinal numbers after back slash, both underlined. To avoid confusion with the previous and forthcoming communications of this series, and since some localities can hopefully be revisited in future, the numeration continues that of the previous communication (Kosterin, 2019a). Disposition of the localities examined is shown on the map of Fig. 1, the basis of which was adopted from Google Earth. Their explanatoins are as follows:

\section{Ratanakiri Province $(\mathrm{Ra})$ :}

64lO'Sieng Lei Waterfall: a series of few tiles of low cascade at a medium-sized river surrounded by a $5 \times 9 \mathrm{~km}$ area of disturbed dipterocarp forest. 19 km SE of Ban Lung. 2.06.2013. 13.5914-5947 N, 107.0833-0886 E, 160-185 m.

65\Katieng Waterfall: The river downstream of the high Katieng Waterfall, with the banks shaded by broad forest stripes, 8 km SSW of Ban Lung, 13.6653-8878' N, 106.9753-9769 E, 200-207 m.

66lLake Kan Seng: a large $(720 \times 320 \mathrm{~m})$ pond with clear water formed by a dammed brook within the town of Ban Lung. 13.7467-7486' N, 106.9817-9861 E, $289 \mathrm{~m}$. 
67\Lake Yak Lom: a perfectly round crater lake, 720 × 750 m, with a clean warm water, banks partly rocky, overgrown with bamboo and/or dipterocarp forest occupying low crater inner slopes, 2.5-3-3 km ESE of Ban Lung, 13.7267-7331 N, 107.0086-0186' E, 302 m.

681Orolestes pool: a shallow hot pool ca 50×20 m where two converging gullies meet a road embankment; a small dipterocarp forest remnant at a hill, a small banana plantation on slopes, rubber plantations around, $7 \mathrm{~km} \mathrm{NEE} \mathrm{of} \mathrm{Ban} \mathrm{Lung,}$ 13.7475-7478 N, 107.0469-0472 E, $368 \mathrm{~m}$.

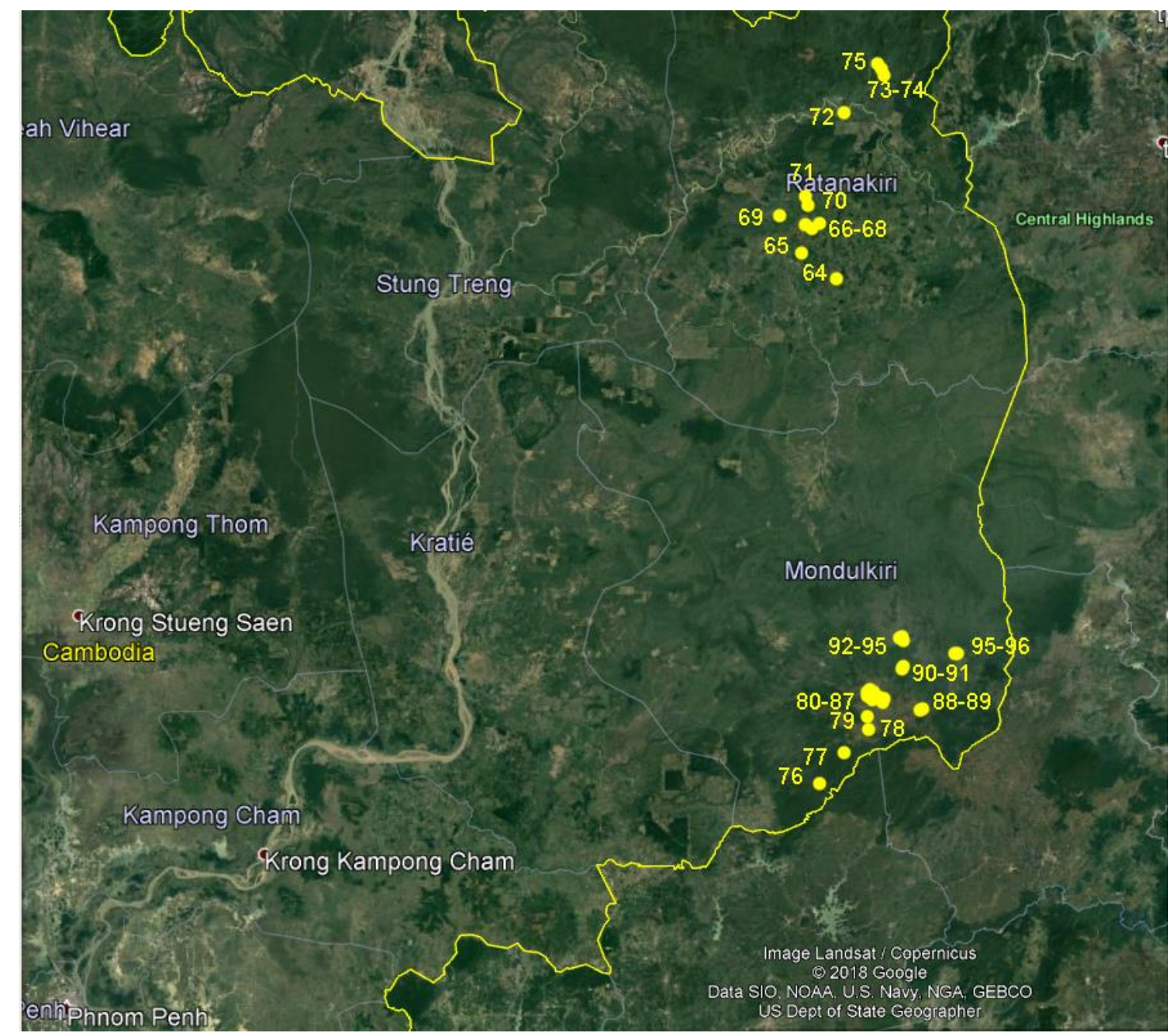

Fig. 1 Disposition of localities where butterfly photos were taken in eastern Cambodia. For explanation of numerals see the text.

69lCha Ong Waterfall: the rivulet upstream Cha Ong Waterfall flowing partly openly above flat rocks, $7 \mathrm{~km}$ WNW of Ban Lung. 13.7592' N, 106.9300-9319 E, 219-221 m.

701O'Chum River: O'Chum River: examined within O'Chum (Khlang Svay) village upstream of the bridge: a small river partly under trees and bushes, partly with grassy (pasture) banks; at the bridge there are areas of inundated low grass and pools surrounded by high grass and bushes. 13.7989-7992 N, 106.9914-9931 E, $250 \mathrm{~m}$.

71 IVeal Rum Plang: Abisaria brook' at Veal Rum Plang Stone Field, a temporal brook with a flat rocky bed shaded by forest, when visited missing flowing water reduced to few pools; flows at a large massif of open dipterocarp forest growing on top of a gentle hill over flat basalt rocks, the flat surface of which is seen on vast openings; the area is legally protected but in fact suffers from logging from the expanding farms. 13.8328-8333 N, 107.0039-0053 E, 315-317 m.

72\Ta Veang: Se San (Tonle San) River right bank at Ta Veang village, a major river with clear water, the level of which fluctuates greatly because of the dam upstream in Vietnam; banks formed by barren clayey ground, mostly with low but steep bluffs, surrounded by small farms. $14.0506 \mathrm{~N}, 107.1078 \mathrm{E}, 100 \mathrm{~m}$.

73lYorn village: O'Tabok River at Yorn village, a considerable river 20-30 m wide with calm flow and clear water, surrounded by small farms still practicing slash-and-burn agriculture and scarce remnants of dipterocarp forest. 14.1439$1444 \mathrm{~N}, 107.2272-2292 \mathrm{E}, 110-115 \mathrm{~m}$.

74IYak Kae Rivulet: in fact a chain of shallow pools, united by a rapidous brook, in secondary tall bamboo stand with solitary trees remaining from recently logged forest. $14.1669 \mathrm{~N}, 107.2125 \mathrm{E}, 139 \mathrm{~m}$.

75\Kong Kreav Veal: at Kong Kreav Veal, a very open dipterocarp savannah (vea), scarcely covered with grass, on a flat surface of a rocky hill Kong Kreav (about 100 m high). 14.1747 N, 107.2186 E, 240 m. 
Mondulkiri Province (Mo):

76।'Lowest river': Seima forest 34 km SW of Sen Monorom - evergreen forest with many seepages; a small rivulet crosses the road and inundates a considerable area of forest; a roadside grassy area, partly inundated. 12.2042-2083 N, 107.0161-0200 E, 302-310 m.

77\'1 $1^{\text {st }}$ river': Seima forest 22.5 km SW of Sen Monorom, A deep valley of quite a large rapidous river; a dark banana grove at a bank, evergreen forest in the valley and on slopes, large and rather intact but with some individual trees cut and a number of temporary forest roads; a shaded small forest brook. 12.2878-2961 N 107.0714-0819 E, 373-397 m.

781O'Rang: $11.5 \mathrm{~km} \mathrm{~S}$ of Sen Monorom, $5 \mathrm{~km}$ NE of O'Rang, a roadside patch of a tall grass in a river valley crossed by the road. $12.3586 \mathrm{~N}, 107.1822-1829 \mathrm{E}, 682 \mathrm{~m}$.

79\O'Romis: $6 \mathrm{~km} \mathrm{~S}$ of Sen Monorom, O'Romis River valley at the power station, a wet grassland near a pond, a road with a canal along a high bluff clad with evergreen shrubbery and forest. $12.4064 \mathrm{~N}, 107.1780 \mathrm{E}, 657 \mathrm{~m}$.

80 Monorom Waterfall: the main river with Monorom Waterfall, relatively large, rapidous river with the forested left bank and partly a stripe of forest and a road at the right bank; examined downstream of a large reservoir with partly forested, partly open banks, and upstream of the hydropower station using the enegry of water flowing from the reservoir through a collateral channel. 12.4419-4442 N, 107.1589-1610 E, 610-622 m a.s.l.

81 Monorom tributary: the valley of a rivulet being the left tributary of the river with Monorom Waterfall; forest and bamboo strips at the banks; the high left slope open, clad with tall grass and bordered with forest above; the valley was nearly pristine in 2014 but partly converted into arable land in 2018. 12.4415-4416 N, 107.1611-1618, 631-633 m a.s.l.

82 1 Sen Monorom W suburbs: $2.2 \mathrm{~km} \mathrm{SW}$ from its centre, a flat ridge with open stand of low trees and tall dipterocarps, bordered with a tall forest margin, ca. $12.440 \mathrm{~N}, 107.179 \mathrm{E}, 690-715 \mathrm{~m}$.

83I'Culminicula Rivulet': 3.5-4 km SE Sen Monorom, a rivulet 2-3 m wide in a valley with patchy forest crossing a savannah plateau, partly shady, partly with open grassy places. 12.4453-4481 N, 107.2167-2222 E, 689-692 m a.s.l.

84ISen Monorom brook: small, with a small pond and a grove in S suburbs $2.4 \mathrm{~km}$ SE from its centre. $12.4472 \mathrm{~N} 107.2031$ $\mathrm{E} 694 \mathrm{~m}$.

$8512.5 \mathrm{~km}$ SE of Sen Monorom: a wet grassy meadow surrounded by bamboo thickets at the bank of the above rivulet in its deep valley downstream of the previous site. $12.4493 \mathrm{~N}, 107.22074 \mathrm{E}, 682 \mathrm{~m}$ a.s.l

86ISen Monorom ponds: two large ponds rimmed with a narrow floating bog formed by Poaceae, banks with small allotments with planted banana, pineapple etc. 12.4603-4611 N 107.1811-1822 $675 \mathrm{~m}$.

87\Long Vibol Guesthouse: in Sen Monorom NE part 1 km from the centre, a garden. 12.4676 N, 107.1925 E, $707 \mathrm{~m}$.

88\Dak Dam: environs of Dak Dam village, with a medium-sized river with bamboo and tree stand at banks; bamboo thickets with a small brook; a small tall-grass (Cyperus sp.) forest swamplets with sparse trees and some sluggish pools; a damp short-grass buffalo pasture with some small pools and Melaleuca bushes. 12.4161-4186 N 107.3172-3206 E, $762-774$ m.

89lDak Dam Waterfall: and a medium-sized river upstream the waterfall, with a strip of forest at banks and a damp shortgrass pasture nearby. 12.4081-4103 N 107.3111-3128 E, 810-815 m,

90\Pulung River: the river name uncertain, in Kosterin (2016) called 'Kruegeri River', 12 km NE of Sen Monorom, between Srae Empum and Buu Sraa villages. Quite a large river with mostly rocky bed but there was an arm with slow current, banks with open dipterocarp stand with tall grass and traces of fire. A grassy open area with a small brook nearby. Until at least 2016 used for pasturing domestic elephants. 12.5161-5211 N 107.2861-2922 E, 530-570 m.

91 \'Genialis brook', 12.8 km NE of Sen Monorom, lower reaches of a brook being the right tributary of the Pulung (?) River, 12.5186-5189 N, 107.2931-2954 E, 529-544 m.

92 \Grassy swamp: in a large glade in an open deciduous dipterocarp forest, $15 \mathrm{~km}$ NNE of Sen Monorom. $12.5771 \mathrm{~N}$ 107.2587 E, $455 \mathrm{~m}$.

93\'Far river': 16 km NNE of Sen Monorom, a small brook flowing in a surprisingly big stony valley, perhaps of a dammed river, with thin tree strips at banks, logged open areas nearby. 12.584-587 N, 107.253-256 E, 400-420 m.

94IDipterocarp forest: open grassy low dipterocarp forest near a rievr $16 \mathrm{~km}$ NNE of Sen Monorom, $5.3 \mathrm{~km}$ SE of Pou Chhrey village. $12.588-590 \mathrm{~N}, 107.245 \mathrm{E}, 405 \mathrm{~m}$.

95\Buu Sraa Waterfall: and surrounding area. a large sunlit grassy 'Plutonia pool' at the right bank of the main river, with a series of small muddy pools on a sunlit narrow grassy floodplain nearly. The main river upstream the waterfalls with banks covered by very open secondary tree and bush stand; immediately upstream the waterfall the banks are open and rocky. The main river between the two tiles of the waterfall: powerful, partly hidden in the forest. The main river just below the waterfalls: large, with banks half open, half forested. A broad grassy floodplain below the waterfall, with open tree stand and traces of fire. 12.5639-5719 N 107.4175-4194 E, 440-504 m.

96ILoringae brook: the left tributary of the main river ca $0.5 \mathrm{~km}$ downstream the Buu Sraa Waterfall. A moderately fast stream, partly shaded by tall forest, partly openly flowing above sandstone rocks until it falls from a high rock. Downstream of this small waterfall it is a winding brook shaded by tall evergreen forest (with traces of old fire) or tall bamboo thickets. 12.5661-5724 N, 107.4139-4175 E, 416-490 m.

For more information about the localities examined, including the landscape and habitat photos, see my odonatological publications concerning Ratanakiri (Kosterin, 2014) and Mondulkiri (Kosterin, 2016) Provinces. 


\section{Results}

The list of butterfly species identified by photos is given below as accompanied with localities, dates and, where possible, sex. For some species a short comment is added. The taxa for the first time reported for Cambodia in scientific literature are marked with asterisk $\left(^{*}\right)$. Presence or absence of Cambodian reports in previous publications was inferred from the summarising Internet site 'Butterflies of Indochina' by Yutaka Inayoshi (2019), the paper by Monastyrskii et al. (2011) and the previous communication of this series (Kosterin, 2019a). Photographs taken in nature (not to scale) illustrate these new country records, as well as most provisional records. Evaluation of rarity of these taxa in the neighbouring Thailand according to Ek-Amnuay (2006) is indicated as §, §§, §§§ from common to rare.

Papilionidae

Troidinae

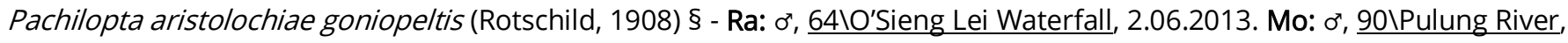
10.06.2014.

Papilioninae

Graphium agamemnon agamemnon (Linnaeus, 1758) §- Ra: ơ, 66।Lake Kan Seng, 6.06.2013; ơơ, 73IYorn village, 5.06.2013.

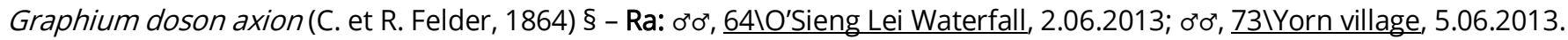
Graphium sarpedon sarpedon(Linnaeus, 1758) §-Ra: $\sigma^{\prime \prime} 0^{\prime \prime}, 731$ Yorn village, 5.06.2013.

Lamproptera meges annamiticus (Fruhstorfer, 1909) §- Mo: 91\'Genialis brook', 25.06.2018; 95\Buu Sraa Waterfall (above), 4.08.2016; 96ILoringae brook, 10.06.2014; ơ, 96ILoringae brook, 24.06.2018.

Papilio clytia clytia (Linnaeus, 1758) § -Ra: ơ f. onape (Moore, 1979), 66ILake Kan Seng, 31.05.2013; ơ f. clytia, 66ILake Kan

Seng, 6.06.2013; ᄋ f. janus (Fruhstorfer, 1908), 67\Lake Yak Lom, 30.05.2013.

Papilio demoleus malayanus Wallace, 1865 § - Ra: ơ, 67\Lake Yak Lom, 31.05.2013; ;, 681Orolestes pool, 7.06.2013; ơ and

ᄋ, 70\O'Chum River, 7.06.2013.

Papilio helenus helenus Linnaeus, 1758 § - Ra: 73IYorn village, 5.06.2013. Mo: 90\Pulung River, 25.06.2018.

Papilio castor mahadeva Moore, [1879] §§ - Mo: ơ, 95\Buu Sraa Waterfall (above), 12.06.2014.

Papilio memnon agenor Linnaeus, $1758 \S$ - Ra: ơ, 66ILake Kan Seng, 3.06.2013. Mo: 9 f. agenor, 87\Long Vibol Guesthouse, 13.06.2014.

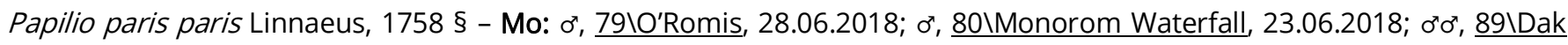
Dam Waterfall, 14.06.2013.

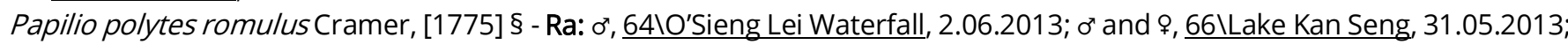

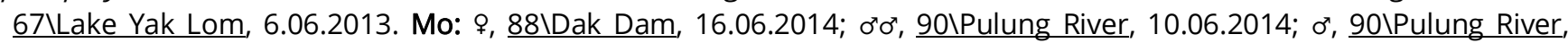
25.06.2018; + , 96ILoringae brook, 9.06.2014.

Pieridae

Pierinae

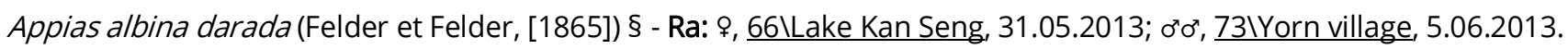
Appias lyncida eleonora (Boisduval, 1836) §- Ra: ơ"',, 73lYorn village, 5.06.2013.

Appias olferna olferna (Swinhoe, 1890) § - Ra: ơ, 67\Lake Yak Lom, 6.06.2013; ๙", 73।Yorn village, 5.06.2013.

Cepora iudith lea (Doubleday,1846) § - Ra: ơ ơ, 73lYorn village, 5.06.2013.

Cepora nerissa dapha (Moore, 1879) § - Ra: o', 73।Yorn village, 5.06.2013.

Delias acalis shinkaii Morita,1998 §§ - Mo: $\underline{87 \backslash L o n g ~ V i b o l ~ G u e s t h o u s e, ~ 13.06 .2014 . ~}$

Delias descombesi descombesi (Boisduval, 1836) §- Mo: $0^{7} \sigma^{7}, 9$, 87\Long Vibol Guesthouse, 8.06.2014; $\sigma^{7}$, 87\Long Vibol

Guesthouse, 13.06.2014; 9 , 87/Long Vibol Guesthouse, 14.06.2014; o', , 87\Long Vibol Guesthouse, 16.06.2014; 9 ,

87\Long Vibol Guesthouse, 17.06.2014; $\sigma^{*}, \underline{91 \backslash^{\prime} G e n i a l i s ~ b r o o k ', ~ 25.06 .2018 . ~}$

Ixias pyrene verna Druce, 1874 § - - Ra: ơ ơ', 73IYorn village, 5.06.2013; Mo: ơơ, 76।'Lowest river', 17.06.2014.

Leptosia nina nina (Fabricius, 1793) §- Ra: 9 , 67\Lake Yak Lom, 30.05.2013.

Pareronia anais anais Lesson, $1837 \S-$ Ra: $\sigma^{\prime \prime}$ 65\Katieng Waterfall, 1.06.2013.

Prioneris philomone clemanthe (Doubleday, 1846) §§ - Ra: ơ, 73।Yorn village, 5.06.2013.

Coliadinae

Catopsilia pomona pomona (Fabricius, 1775) § - Ra: o f. crocale (Cramer, 1775), 66lLake Kan Seng, 31.05.2013; o f jugurtha (Cramer, 1777),66lLake Kan Seng, 6.06.2013; ơơ f. pomona, 73IYorn village, 5.06.2013. Mo: ơ f. alcmeone (Cramer, 1775), 87\Long Vibol Guesthouse, 16.06.2014.

Eurema blanda silhetana (Wallace, 1867) § - Mo: 83।'Culminicula Rivulet', 8.06.2014.

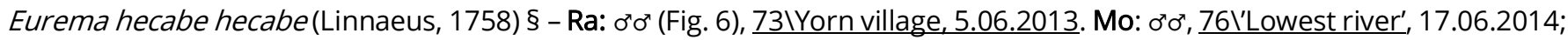

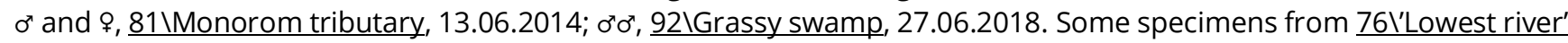
(Figs. 2-3) and 92\Grassy swamp had reduced dark markings on UNS, with no inner spots and only a trace of apical spot 
in the UNF cell. They occurred together with regular specimens with usual markings (Fig. 3) and could represent a different seasonal cohort.

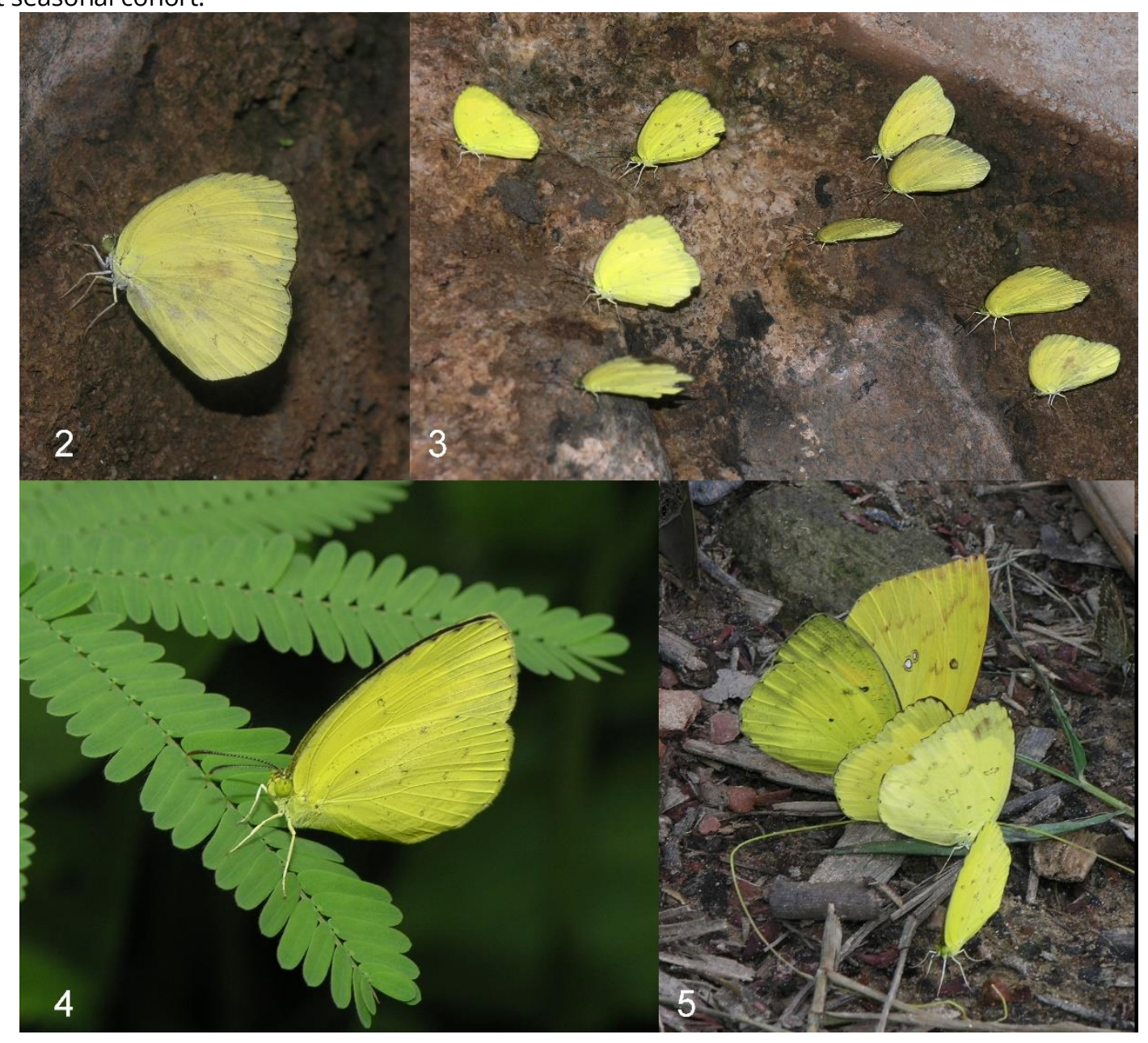

Figs. 2-5 Problematic Eurema spp. from eastern Cambodia: 2 - E. hecabe hecabe, a male with reduced UNS dark markings, 76I'Lowest river', 17.06.2014; 3 - similar males in a company with those with normally developed UNS marking in the same place; 4 - Eurema sp. with only apical comma-like spot in cell, 73ıYorn village, 5.06.2013; 5 - a similar male (below) in a company of two males of $E$. hecabe hecabe (in the centre), and also a male of Ixias pyrene verna and a female of Catopsilia pomona pomonaf. pomonain the same place. Not to scale.

Eurema sp. - Ra: $0^{\top} \sigma^{\prime \prime}, 73 \backslash$ Yorn village, 5.06.2013. UNF has a well expressed comma-like cell-end spot, as in $E$. hecabe, E. sari (Horsfield, 1829), E. andersoni (Moore, 1886) but, unlike these species, no any spot inside the cell. Also UNF without apical dark wash (unlike E. sarl), the UPF black border is seen through as having a deep incision (as in $E$. hecabe and $E$. andersoni), but the HW outer margin is rounded rather than subungulate (unlike E. hecabe) (Fig. 4). In the photograph of Fig. 5 this species is in a company of $E$. hecabe with normally developed markings.

Lycaenidae

\section{Riodinidae}

* Abisara cf. bifasciata angustilineata Inoue et Kawazoe, 1965 §§§ - Ra: ơ, 71\Veal Rum Plang, 07.06.2013 (Fig. 6).

Abisara latifasciata Inoué \& Kawazoé,1964 - Mo: ơ, 94\Dipterocarp forest, 27.06.2018; ơ, 95\Buu Sraa Waterfall (below), 12.06.2014 (Fig. 7).

Poritiinae

*Poritia cf. hewitsoni Moore, [1866] §§§ - Mo: ơ, 81\Monorom tributary, 13.06.2014 (Figs 8-9).

The UPF pattern (Fig. 9) fits more Poritia erycinoides elsiei (Felder et Felder, 1865) because of the black areas reduced in the upper part, leaving considerable blue patches in postdiscal and sumbarginal areas but enhanced in space $1 \mathrm{~b}$ harbouring two black spots. However, the greenish-light-blue ground colour fits $P$. hewitsoni. Since the iridescent metallic colour seems to be a better species recognition cue than pattern details, which are quite variable in males of both species, I incline to identify this insect as $P$. hewitsoni. 
Theclinae

* Ahmetia achaja achaja (Fruhstorfer, ) §§§ - Ra: , 75\Kong Kreav Veal, 04.01.2013 (Fig. 10).

Amblypodia anita anita Hewiston, 1862 §§ - Ra: 9 , 67\Lake Yak Lom, 30.05.2013. Mo: 95\Buu Sraa Waterfall, 4.08.2016.

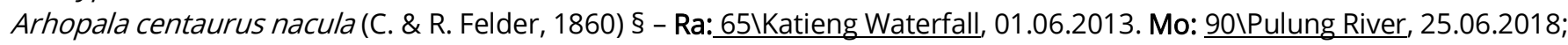
95\Buu Sraa Waterfall (just above), 15.06.2014.

Arhopala elopura Druce, 1794 ssp. §§ - Mo: 95\Buu Sraa Waterfall (below), 12.06.2014 (Fig. 11). The doubtless belonging to the alitaeus-group, absence of a spot at the base of space 10 on UNF and UNS maculation hardly darker than the background leads to $A$. elopura (Corbet, 1941; Eliot, 1957; Seki et al, 1991), while absence of a purple wash on UNS to its undescribed Indochinese subspecies (Inayoshi, 2019).

*Arhopala nicevillei Bethune-Baker, 1903 §§ - Mo:, 90\Pulung River, 25.06.2018 (Fig. 12). The female laid eggs on young sprouts of low dipterocarp trees, each time by one or few and then changed a tree.

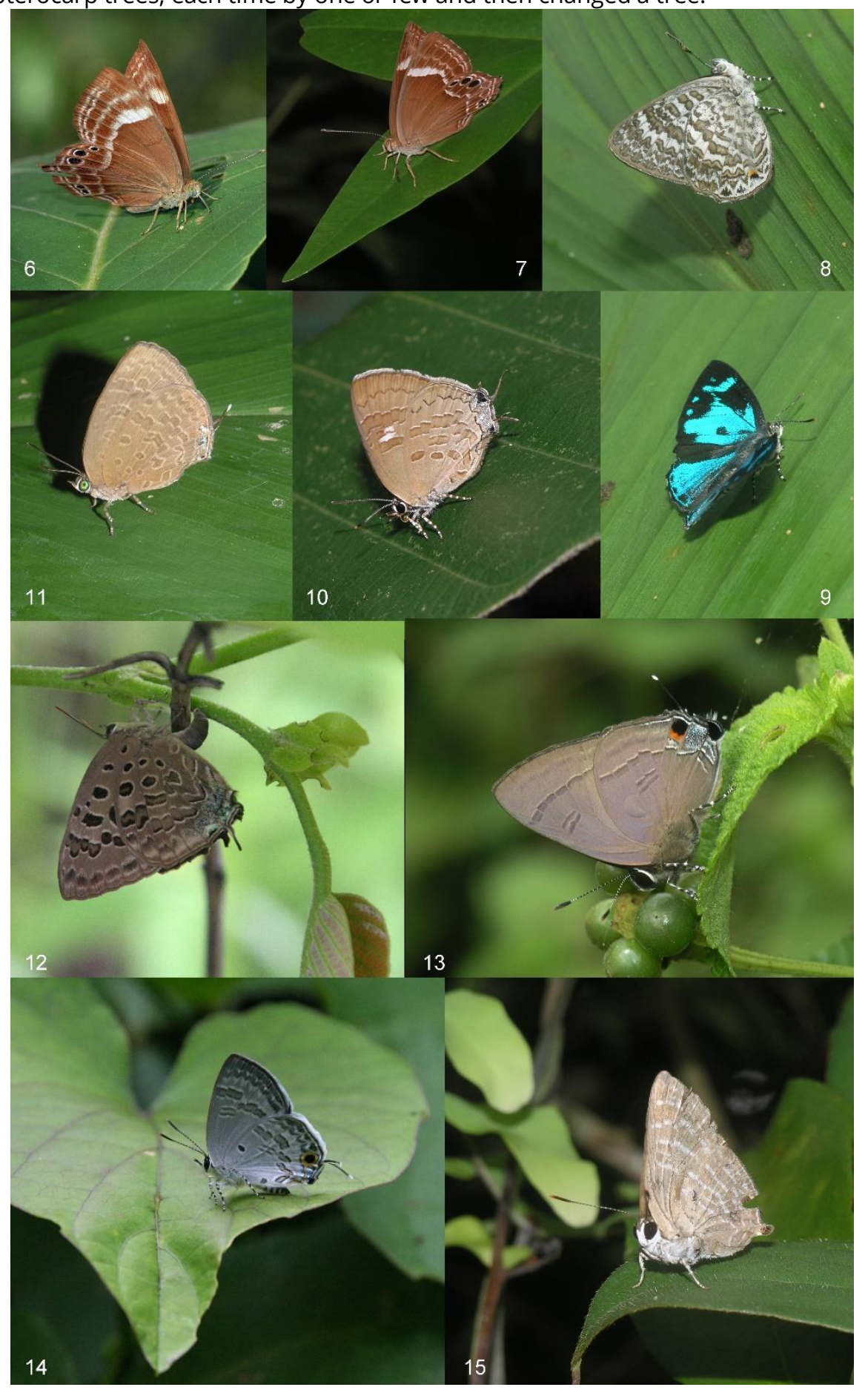

Figs. 6-15 New for Cambodia or provisionally identified Lycaenidae (Riodininae, Poritinae and Theclinae) from Eastern Cambodia: 6 - Abisara cf. bifasciata angustilineata, on, 71 IVeal Rum Plang, 07.06.2013; 7 - A. latifasciata, on, below $\underline{95 \backslash B u u}$ Sraa Waterfall, 12.06.2014; 8-9 - Poritia cf. hewitsoni, ơ, 81 Monorom tributary, 13.06.2014; 10 - Ahmetia achaja achaja, 9 , 75\Kong Kreav Veal, 04.01.2013; 11 - Arhopala elopura ssp., below 95\Buu Sraa Waterfall, 12.06.2014; 12 - A. nicevillei, ,

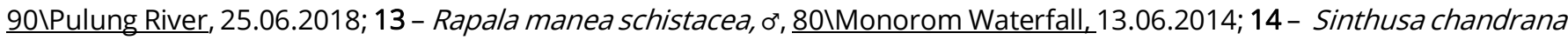
grotei, 79\O'Romis, 28.06.2018; 15 - Virachola sp. cf. kessuma, 88\Dak Dam (a tall Cyperus swamplet), 16.06.2014. Not to scale. 
Cheritra freja evansi Cowan, 1965 § - Mo: 96।Loringae brook, 24.06.2018.

Hypolycaena amasa amasa (Hewiston, [1865]) §§ - Ra: $0^{\Uparrow}, 681$ Orolestes pool, 07.06.2013.

Hypolycaena erylus himavantus Fruhstorfer, $1912 \S$ - Ra:73lYorn village, 05.06.2013. Mo: ơ, 90।Pulung River, 10.06.2014. Hypolycaena thecloides thecloides (C. \& R. Felder, 1860) §§- Mo: 88lDak Dam, 16.06.2014.

Loxura atymnus continentalis Fruhstorfer, [1912]) §- Ra: 69lCha Ong Waterfall, 31.05,.2013; 73lYorn village, 03.06.2013.

Mo: 821Sen Monorom W suburbs, 11.06.2014.

Rapala iarbus (Fabricius, 1787) § - Mo: 9, 821Sen Monorom W suburbs, 11.06.2014; 9, 94IDipterocarp forest, 27.06.2018.

Rapala manea schistacea (Moore, 1879) §§ - Mo: ơ, 80\Monorom Waterfall, 13.06.2014 (Fig. 13).

Rapala pheretima petosiris (Hewiston, 1863) § - Ra: ơ, 731Yorn village, 03.06.2013.

* Sinthusa chandrana grotei (Moore, 1884) §§§ - Mo: 7910’Romis (on vegetation covering a cliff facing a road and an open place), 28.06.2018 (Fig. 14).

Surendra quercetorum quercetorum (Moore, 1858) §- Ra: \$, 65\Katieng Waterfall, 01.06.2013; 73।Yorn village, 05.06.2013.

Mo: 86ISen Monorom ponds, 8.06.2014; 96ILoringae brook, 10.06.2014.

*Virachola sp. cf. kessuma (Horsfield, 1829) - Mo: 88IDak Dam (a tall Cyperus swamplet), 16.06.2014. The UNS pattern in the photographed individual resembles that of $V$. kessuma, which ranges in the Malay Peninsula and is known to reach in the north only Peninsular Thailand, but has the UNH discal and postdiscal white pattern less regular (more distorted). Deudoryx epijarbas (Moore, [1858]) also has white streaky UNH pattern but the UNF postdiscal streaks are straight while the discal streaks do not extend beneath the cell, and the UNH pattern is again more distorted. The photographed individual could represent an undescribed taxon. It perched on a sunlit bush leaf, made very fast flights from there, flew actively and returned back (as dragonfly males usually do).

Yasoda tripunctata tripunctata (Hewiston, 1863) §§ - Mo: 76/'Lowest river', 17.06.2014.

Polyommatinae

Acytolepis puspa gisca (Fruhstorfer, 1910) §- Ra: ơ, 74IYak Kae Rivulet, 04.06.2013. Mo: 90lPulung River, 25.06.2018.

Caleta decidia decidia (Hewiston, [1876]) §§ - Mo: 84ISen Monorom brook, 8.06.2014.

Caleta roxus roxana (de Niceville, 1897) §§ - Ra: $0^{\prime}$, 681Orolestes pool, 30.05.2013.

Chilades lajus lajus (Stoll, [1780]) § - Mo: $\sigma^{n}$, 87\Long Vibol Guesthouse, 4.08.2016.

Chilades pandava pandava (Horsfield, [1829]) § - Mo: ơ, 87ILong Vibol Guesthouse, 9.06.2014; 88IDak Dam, 16.06.2014. Discolampa ethion ethion (Fabricius, 1775) §§ - Mo: 77/'1 $1^{\text {st }}$ river', 17.06.2014.

Jamides sp. - Ra: 9 , 67\Lake Yak Lom, 20.05.2013.

Lampides boeticus (Linnaeus, 1758) § - Mo: $\$$, 80\Monorom Waterfall (at the dam), 13.06.2014

Nacaduba cf. beroe gythion Fruhstorfer, 1916 §§ - Mo: 82\Sen Monorom W suburbs, 11.06.2014 (Fig. 16).

Pithecops corvus correctus Cowan, 1966 §§ - Mo: 96।Loringae brook, 15.06.2014.

Udara/Celastrina sp. - Mo: 88\Dak Dam (a tall Cyperus swamplet), 16.06.2014 (Fig. 17).

*Zizeera maha maha (Kollar, 1848) § - Mo: 87/Long Vibol Guesthouse, 7.06.2014 (Fig. 18).

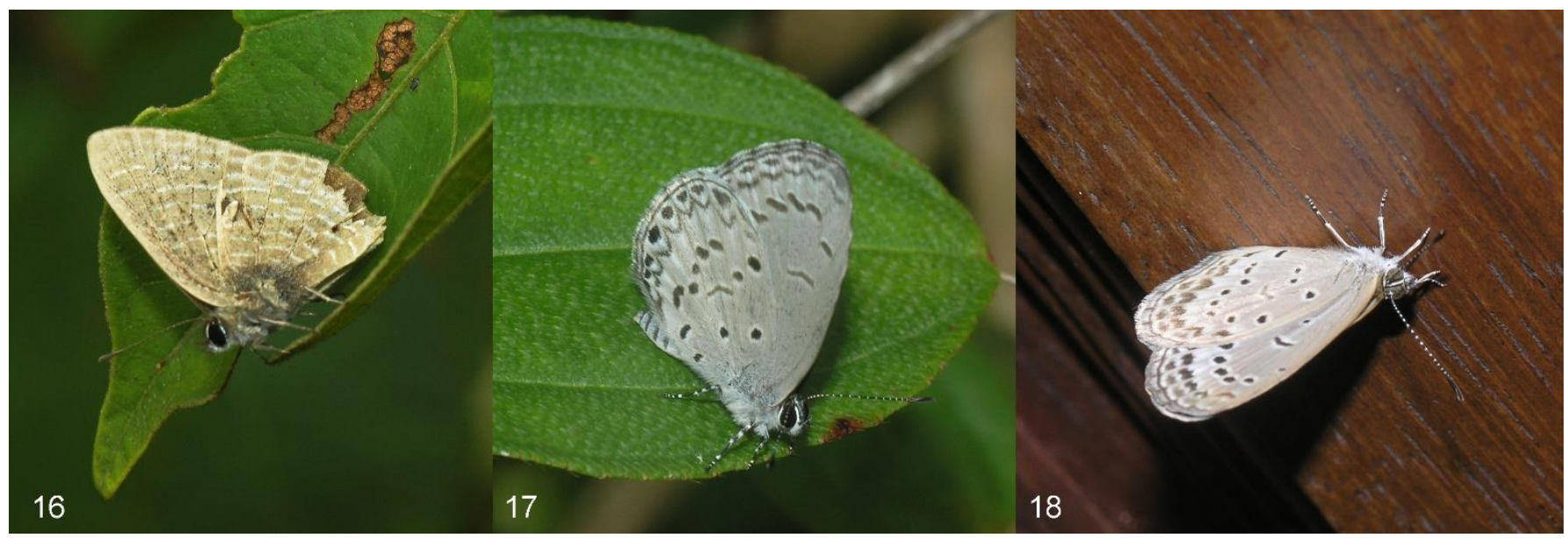

Figs. 16-18 Polyommatinae from eastern Cambodia (a provisionally identified, an unidentified and a new for Cambodia): 16 - Nacaduba cf beroe gythion, 821Sen Monorom W suburbs, 11.06.2014; 17 - Udara/Celastrina sp., 88IDak Dam (a tall Cyperus swamplet), 16.06.2014; 18 - Zizeera maha maha, 87ILong Vibol Guesthouse, 7.06.2014. Not to scale. 
Nymphalidae

Danainae

Danaus genutia genutia (Cramer, 1779) § - Ra: $\sigma^{\prime}, 721$ Ta Veang, 3.06.2013.

Euploea core godarti Lucas, 1853 § - Ra: ơ f. layardi, 72\Ta Veang, 3.06.2013.

Euploea algea menetriesi C. et R. Felder, $1860 \S-\mathrm{Ra}$ : $\sigma^{\prime}$, 72\Ta Veang, 3.06.2013. (E. modesta is ruled out as the butterfly photographed was distinctly larger than E. radamanthus in the same shot and has the outer forewing margin convex.).

Euploea doubledayi doubledayi (C. \& R. Felder, 1860) §§ - Ra: $0^{7}$, 72\Ta Veang, 3.06.2013.

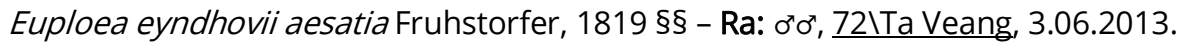

Euploea mulciber mulciber (Cramer, 1777) §- Ra: $\sigma^{\top} 0^{\prime \prime}$, 72\Ta Veang, 3.06.2013. Mo: m, 93।'Far river', 26.06.2018.

Euploea radamanthus radamanthus (Fabricius, 1793) § - Ra: ơ $0^{n}$, 721Ta Veang, 3.06.2013.

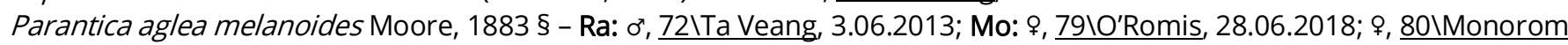

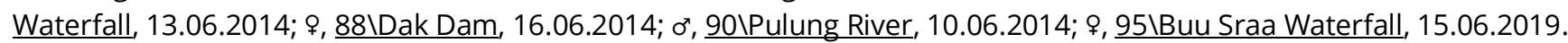

*Tirumala limniace limniace (Cramer, 1775) § - Mo: 93।'Far river', 26.06 .2018 (Fig. 19).

Tirumala septentrionis septentrionis (Butler, 1874) § - Ra: ${ }^{\star \prime}$, 721Ta Veang, 3.06.2013.

Cyrestinae

Cyrestis themire themire Honarth, 1884 § - Mo: ơ' $0^{\prime}$, 76I'Lowest river', 17.06.2014.

Biblidinae

Ariadne ariadne pallidior (Fruhstorfer, 1899) § - Ra:64IO'Sieng Lei Waterfall, 2.06.2013; 67\Lake Yak Lom, 31.05.2013.

Ariadne merione tapestrina (Moore, 1884) § - Mo: 95\Buu Sraa Waterfall (above), 4.08.2016.

Ariadne specularia arca (Fruhstorfer, 1906) § - Ra: 74lYak Kae Rivulet, 4.06.2013

Nymphalinae

Hypolymnas bolina jacintha (Drury, [1773]) § - Ra: ơ, 66lLake Kan Seng, 06.06.2013.

Junonia almana almana (Linnaeus, 1758) § - Ra: 66lLake Kan Seng, 30.05.2013; 7010'Chum River, 7.06.2013; 73IYorn village, 3.06.2013.

Junonia atlites atlites (Linnaeus, 1763) § - Mo: 90\Pulung River, 10.06.2014.

*Junonia hierta hierta (Fabricius, 1798) §-Ra: 9, 66।Lake Kan Seng, 31.05.2013 (Fig. 20); Mo: \$, 95\Buu Sraa Waterfall (below the lower tile), 4.08.2016 (Fig. 21).

Junonia iphita iphita (Cramer, 1779) §§ - Ra: 67\Lake Yak Lom, 2.06.2013, 30.05.2013. Mo: 821Sen Monorom W suburbs,

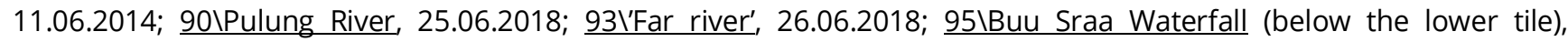
4.08.2016.

Junonia lemonias lemonias (Linnaeus, 1758) §- Ra: 66ILake Kan Seng, 31.05.2013; ơ and \&, 66ILake Kan Seng, 6.06.2013.

Mo: 94lDipterocarp forest, 27.06.2018.

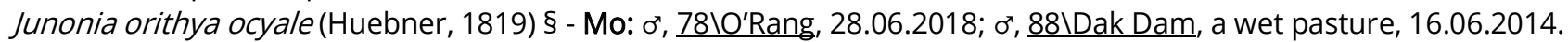

*Kallima inachus alboinachus Nakamura et Wakahara, 2013 - Mo: ơ $0^{\prime \prime}$, 93l'Far river', 26.06.2018 (Figs 22-23); ơ, 96lLoringae brook, 24.06.2018 (Fig. 24). The males met in Mondulkiri Province had a white UPF band (Fig. 23) that corresponds to the subspecie alboinachus described from Laos and also known to occur in S Vietnam and E Thailand (Nakamura, 2014), hence its occurrence in E Cambodia was expectable. In the Cardamom Mts. in SW Cambodia, $K$. inachus siamensis Fruhstorher, 1912 occurs (Monastyrskii et al., 2011; Kosterin, 2019a).

Kaniska canace canace (Linnaeus, 1763) §§ - Mo: \&, 95\Buu Sraa Waterfall (the main river valley upstream of), 10.08.2014; 95।Buu Sraa Waterfall, 15.06.2014.

*Yoma sabina vasuki Doherty, [1886] §§ - Mo: 93\’Far river', 26 and 27.06.2018 (Figs 26-27); 95\Buu Sraa Waterfall (above), 4.08.2016 (Fig. 25).

Heliconiinae

Acraea violae (Fabricius, 1793) §- Ra: $0^{\top} 0^{\top}, 66$ LLake Kan Seng, 31.05.2013.

Cethosia cyane euanthes (Fruhstorfer, 1912) §- Mo: $\sigma^{\star}$, 95।Buu Sraa Waterfall (the main river valley upstream of), 15.06.2014. Cirrochroa tyche mithila Moore, 1872 § - Ra: $0^{7}$, 66ILake Kan Seng, 31.05.2013; 9 , 71IVeal Rum Plang, 07.06.2013.

Cupha erymanthis erymanthis (Drury, [1773]) \& - Mo: 96ILoringae brook, 12.06.2014.

Terinos trepander intermedia Godfrey, 1916 §§ - Ra: 9, 73।Yorn village, 3.06.2013; ơ, 73।Yorn village, 4.06.2013.

* Terinos clarissa falcata Fruhstorfer, 1898 §§ - Ra: ơ, 67\Lake Yak Lom, 6.06.2013 (Fig. 28). Identified by falcate wings and the UNF apical vague whitish spot situating above rather than below the darker spot (Fig. 28) (as kindly adviced by

Antonio Giudici based on Y. Inayoshi's pers. comm.).

Vagrans sinha sinha (Kollar, [1884]) § - Mo: $\sigma^{\top}$, 90lPulung River, 10.06.2014.

Vindula erota erota (Fabricius, 1798) §- Ra: $\sigma^{\alpha}$, 73IYorn village, 3.06.2013; Mo: $\sigma^{\star},\left.76\right|^{\prime}$ 'Lowest river', 17.06.2014.

Vindula dejone erotella (Butler, [1879]) § - Ra: ơ, 73।Yorn village, 5.06.2013. 


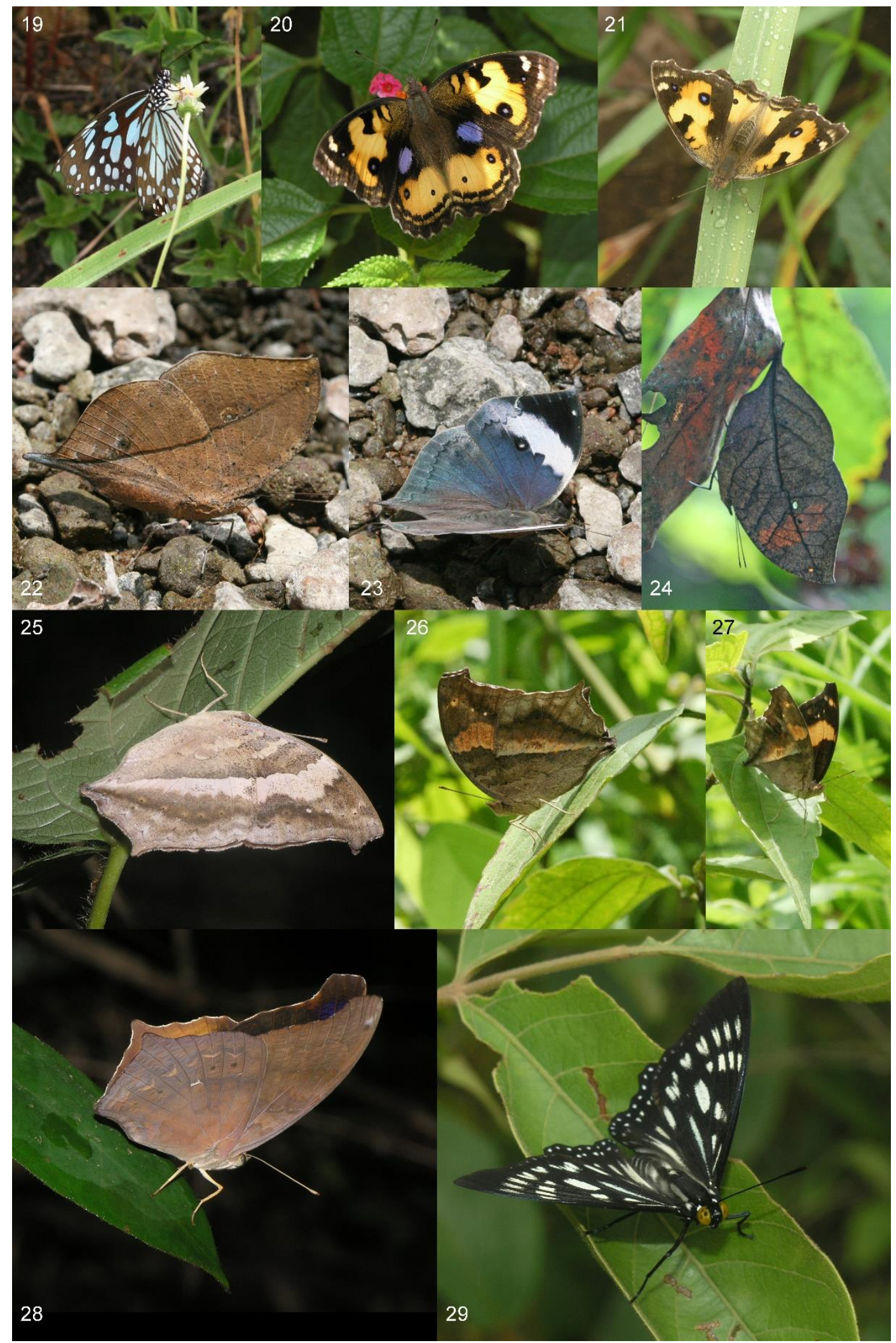

Figs. 19-29 Nymphalidae (Danainae, Nymphalinae, Heliconiinae and Apaturinae) new for Cambodia: 19 - Tirumala limniace limniace, 93।'Far river', 26.06.2018; 20-21 - Junonia hierta hierta: oo, 20 - 66lLake Kan Seng, 31.05.2013, 21 - below the lower tile of 95\Buu Sraa Waterfall, 4.08.2016; 22-24 - Kallima inachus alboinachus. 22-23 - ơo', 93\'Far river', 26.06.2018, 24 - o', 96\Loringae brook, 24.06.2018; 25-27 - Yoma sabina vasuki: 25 - above 95\Buu Sraa Waterfall, 4.08.2016, 26-27 93\'Far river', 26 and 27.06.2018; 28 - Terinos clarissa falcata, ơ, 67\Lake Yak Lom, 6.06.2013; 29 - Euripus nyctelius nyctelius, $\sigma^{\prime \prime}, \underline{821 S e n}$ Monorom W suburbs, 11.06.2014. Not to scale. 
Limenitinae

Athyma perius perius (Linnaeus, 1758) § - Mo: $\underline{82 \backslash S e n ~ M o n o r o m ~ W ~ s u b u r b s, ~} 11.06 .2014 ;$ 81 \Monorom tributary, 13.06.2014; 83।'Culminicula Rivulet', 23.06.2018; 93।'Far river', 26.06.2018.

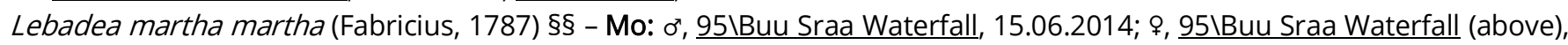
4.08.2016.

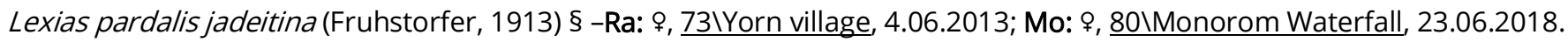
Moduza procris procris Cramer, $1777 \S$ - Mo: $77 \backslash^{\prime} 1^{\text {st }}$ river', 17.06.2014.

Neptis hylas kamarupa Moore, 1875 § - Ra: 73IYorn village, 3.06.2013. Mo: (id. uncertain), 89\Dak Dam Waterfall, 16.06.2014; 95\Buu Sraa Waterfall, 15.06.2014.

Neptis nata adipata Moore, 1872 §§ - Mo: 81 Monorom tributary, 13.06.2014.

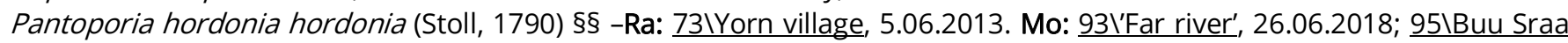
Waterfall, 15.06.2014.

Parthenos sylla apicalis Moore, 1878 §§ - Ra: 65\Katieng Waterfall, 1.06.2013; 73\Yorn village, 3.06.2013. Mo: $\underline{89 \backslash D a k ~ D a m}$ Waterfall, 16.06.2014.

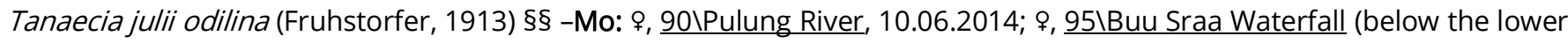
tile), 12.06.2014.

Apaturinae

*Euripus nyctelius nyctelius (Doubleday, 1845) §- Mo: ơơ, 821Sen Monorom W suburbs, 11.06.2014 (Fig. 29).

Charaxinae

Charaxes berdardus hierax C. \& R. Felder, [1867] f. hierax $\S$ - Mo: 88\Dak Dam, a river bank, 16.06.2014.

Charaxes solon sulphureus Rothschild, 1900 § - Mo: o', 90\Pulung River, 10.06.2014; o', 93\'Far river', 26.06.2018.

Polyura arja arja (C. et R. Felder, 1867) §§ - Ra: 74lYak Kae Rivulet, 4.06.2013 (Fig. 30). Mo: 88\Dak Dam, 16.06.2014; ơo", 93\'Far river', 26-27.06.2018 (Fig. 31).

Polyura athamas athamas (Drury, [1773]) § - Ra: 71 IVeal Rum Plang, 07.06.2013; 74IYak Kae Rivulet, 4.06.2013 (Fig. 32). Mo: o', 93\'Far river', 27.06.2018 (Fig. 33). This species was distinguished from the previous one by a narrower subapical spot and the upper end of the pale band on UNF, as illustrated by two pairs of photos of both species met together at Yak Kae Rivulet in Ratanakiri (4.06.2013) (Figs 30 and 32) and Far River in Mondulkiri (27.06.2018) (Figs 31 and 33).
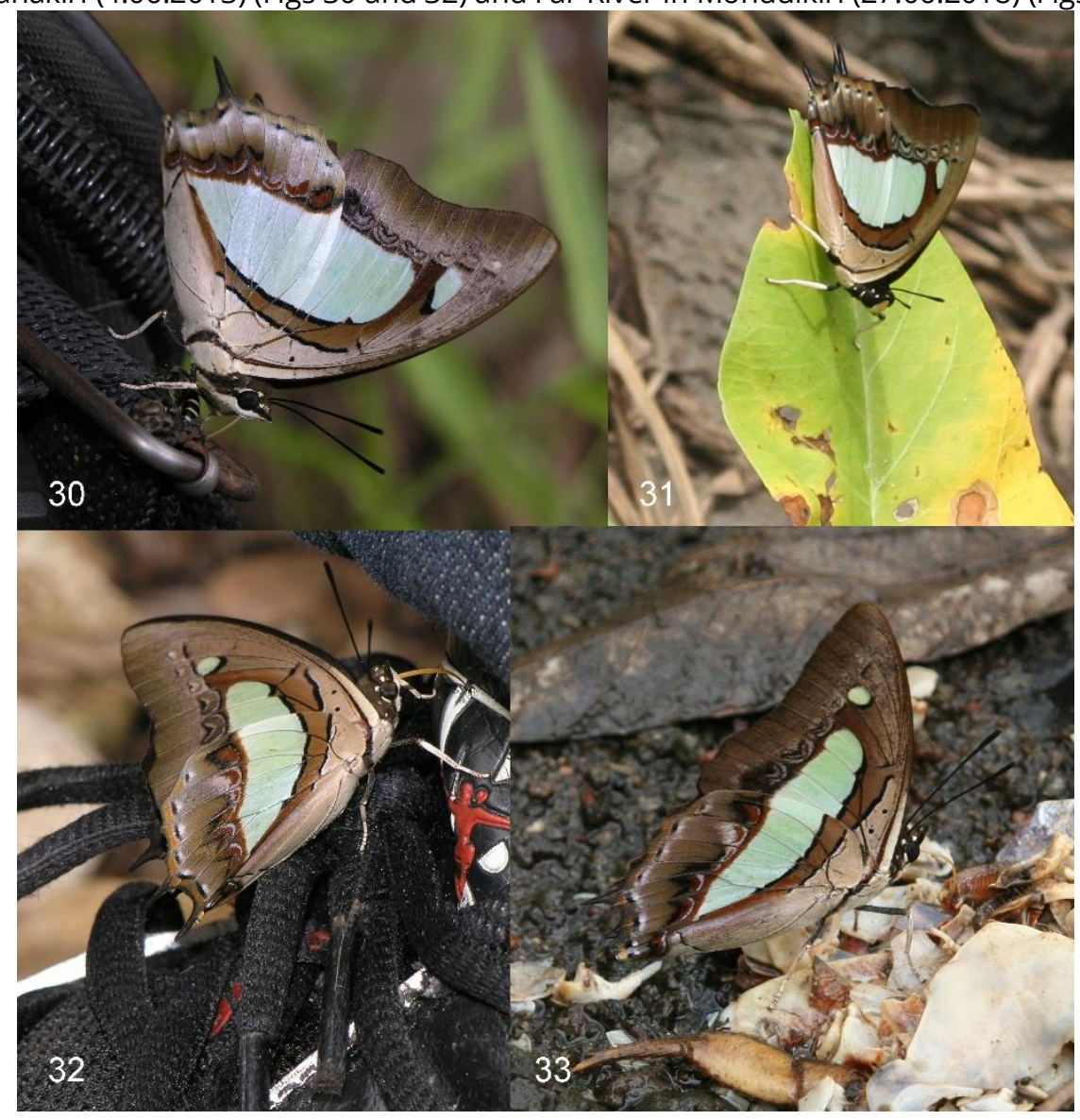

Figs. 30-33 Both Polyura arja arja (30-31) and Polyura athamas athamas (32-33) photographed in two localities of eastern Cambodia: : 74IYak Kae Rivulet, 4.06.2013 (30, 32) and 93।'Far river', 27.06.2018 (31, 33). Not to scale. 
Satyrinae

Coelites nothis nothis Westwood, 1850 §§§ - Ra: 73।Yorn village, 4.06.2013

* Lethe rohria rohria (Fabricius, 1787) § - Mo: $९, 85 \backslash 2.5$ km SE of Sen Monorom, 23.06.2018 (Fig. 34);, 88\Dak Dam, 16.06.2014 (Fig. 35).

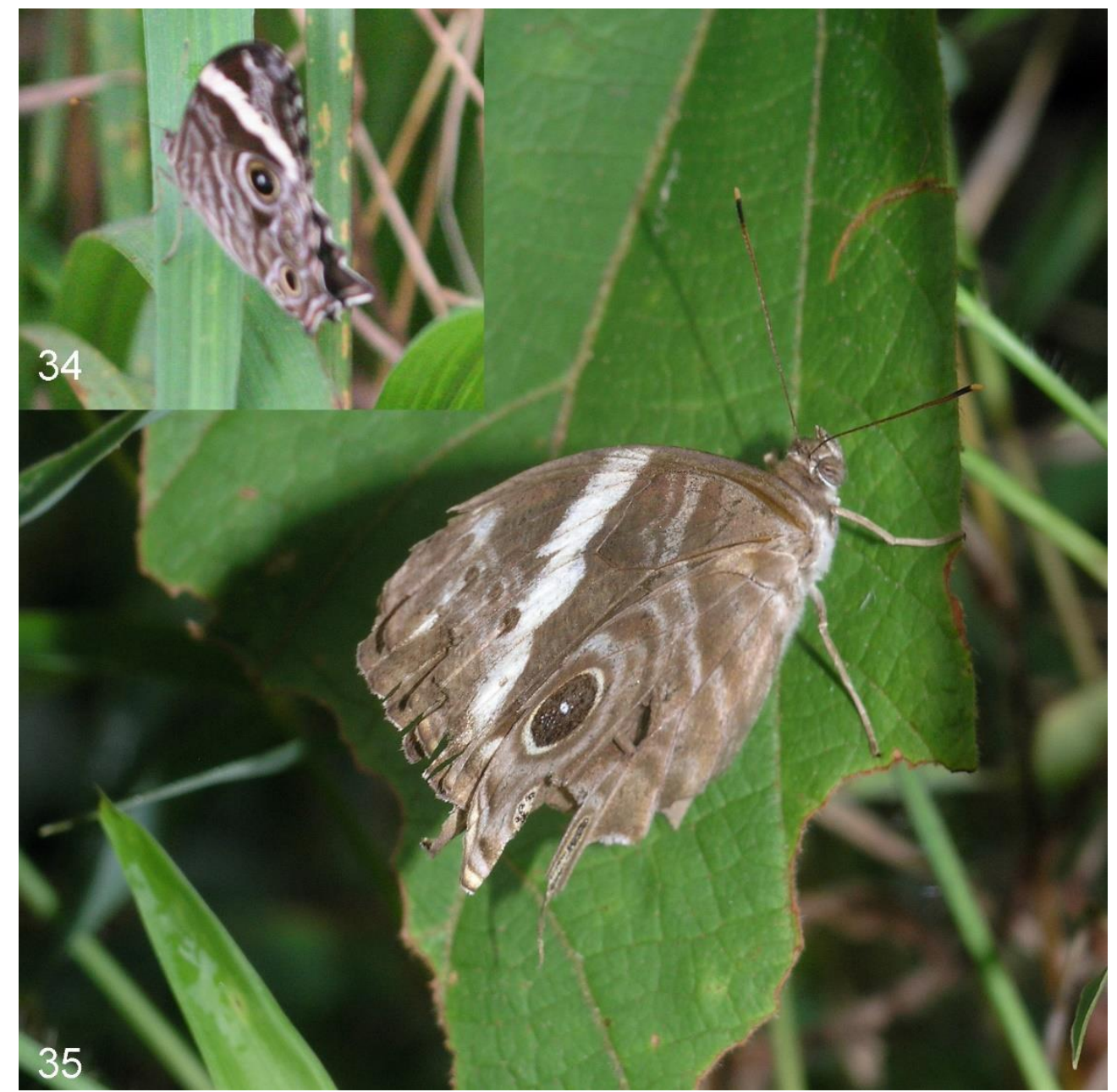

Figs. 34-35 Females of Lethe rohria rohria, new for Cambodia, in Mondulkiri Province: 34 - $85 \backslash 2.5$ km SE of Sen Monorom, 23.06.2018; 35 - 88\Dak Dam, 16.06.2014. Not to scale.

Lethe minerva tritogenites Fruhstorfer, $1911 \S$ - Ra: $\sigma^{7}, 67$ Lake Yak Lom, 31.05.2013.

Melanitis spp. - Ra:68\Orolestes pool, 6.06.2013. Mo: 81\Monorom tributary, 13.06.2014; 83\'Culminicula Rivulet', 8.06.2014; 95\Buu Sraa Waterfall (below), 4.08.2016.

Mycasesis spp. - Ra: ơơ, \&, 66\Lake Kan Seng, 6.06.2013. Mo: 95\Buu Sraa Waterfall (below), 4.08.2016.

Orsotriaena medus medus (Fabricius, 1775) § - Ra: 73।Yorn village, 4.06.2013.

Hesperiidae

Coeliadinae

* Bibasis sena sena (Moore, 1866) §§ - Ra: 73ıYorn village, 4.06.2013 (Fig. 36).

Pyrginae

* Caprona agama agama (Moore, 1858) § - Ra: 69lCha Ong Waterfall, 31.05.2013 (Fig. 37).

*Caprona alida alida (de Niceville, 1891) §§§ -Mo: 84ISen Monorom brook, 8.06.2014 (Fig. 38).

Odontoptilum angulatum angulatum (C. Felder, 1862) § - Mo: 90\Pulung River, 10.06.2014.

Tagiades gana meetana Moore, 1879 § - Mo: 79lO’Romis, 28.06.2018.

Tagiades vajuna vajuna Fruhstorfer, 1910 § - Ra: 73ıYorn village, 4.06.2013.

Hesperiinae

*Aeromachus cf. pygmaeus (Fabricius, 1775) §§§ - Mo: 86\Sen Monorom ponds, 8.06.2014 (Fig. 39).

Ampittia dioscorides camertes (Hewiston, 1868) § - Mo: 96।Loringae brook, 3.08.2016. 


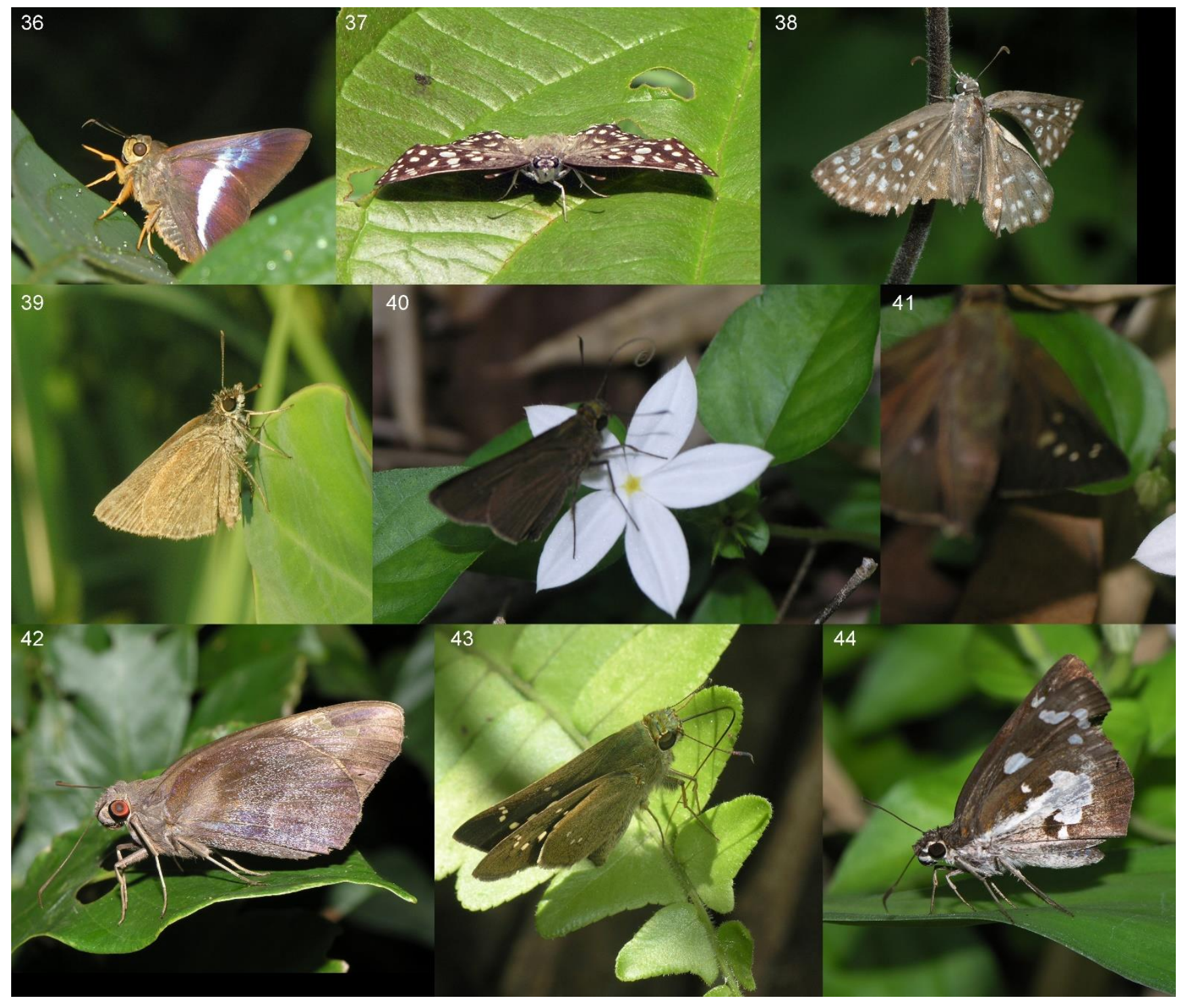

Figs. 36-44 Hesperiidae, new for Cambodia or provisionally identified: 36 - Bibasis sena sena, 73IYorn village, 4.06.2013; 37 - Caprona agama agama, 69\Cha Ong Waterfall, 31.05.2013; 38 - Caprona alida alida, 84ISen Monorom brook, 8.06.2014; 39 - Aeromachus cf. pygmaeus, 86ISen Monorom ponds, 8.06.2014; 40-41 - ?Caltoris sp., Ra: 67\Lake Yak Lom, 30.05.2013; 42 - Gangara thyrsis thyrsis, 73IYorn village, 4.06.2013; 43 - Pelopidas cf. mathias mathias, 95\Buu Sraa Waterfall (in sprey area just below the upper tile), 4.08.2016; 44 - Udaspes folus, 67\Lake Yak Lom, 30.05.2013. Not to scale.

Ancistroides nigrita maura (Snellen [1880]) § - Mo: 95\Buu Sraa Waterfall (at headquarters), 3.08.2016.

Astictopterus jama olivascens Moore, 1878 § - Mo: 88\Dak Dam, 16.06.2014.

?Caltoris sp. - Ra: 67lLake Yak Lom, 30.05.2013 (Figs 40-41).

* Gangara thyrsis thyrsis (Fabricius, 1775) § - Ra: 73IYorn village, 4.06 .2013 (Fig. 42).

lambrix salsala salsala (Moore, [1866]) § - Ra: 65\Katieng Waterfall, 1.06.2013. Mo: 95\Buu Sraa Waterfall (at headquarters), 15.06.2014.

Notocrypta paralysos asawa Fruhstorher, 1911 § -Ra: 73\Yorn village, 4.06.2013. Mo: , 17.06.2014. 95\Buu Sraa Waterfall (at headquarters), 3.08.2016.

Pelopidas cf. mathias mathias (Fabricius, 1798) § - Mo: 95\Buu Sraa Waterfall (in sprey area just below the upper tile), 4.08.2016 (Fig. 43).

Taractrocera archias quinta Swinhoe, 1913 §§ - Ra: 681Orolestes pool, 7.06.2013.

Thoressa masoni (Moore, 1878) § - Ra: 73IYorn village, 5.06.2013.

*Udaspes folus (Cramer, 1775) §§ - Ra: 67\Lake Yak Lom, 30.05.2013 (Fig. 44). 


\section{Updates to the first communication of this series (Kosterin 2019a)}

Rapala manea schistacea was reported (but not illustrated) from 5\Koh Kong, NE suburbs, 14.04.2010 in error (a misidentification). The photo, shown here in Fig. 45, probably shows a female of Rapala dieneces (Hewitson, [1878]). Nevertheless, the true $R$. manea schistacea is reported here (see above; Fig. 13).

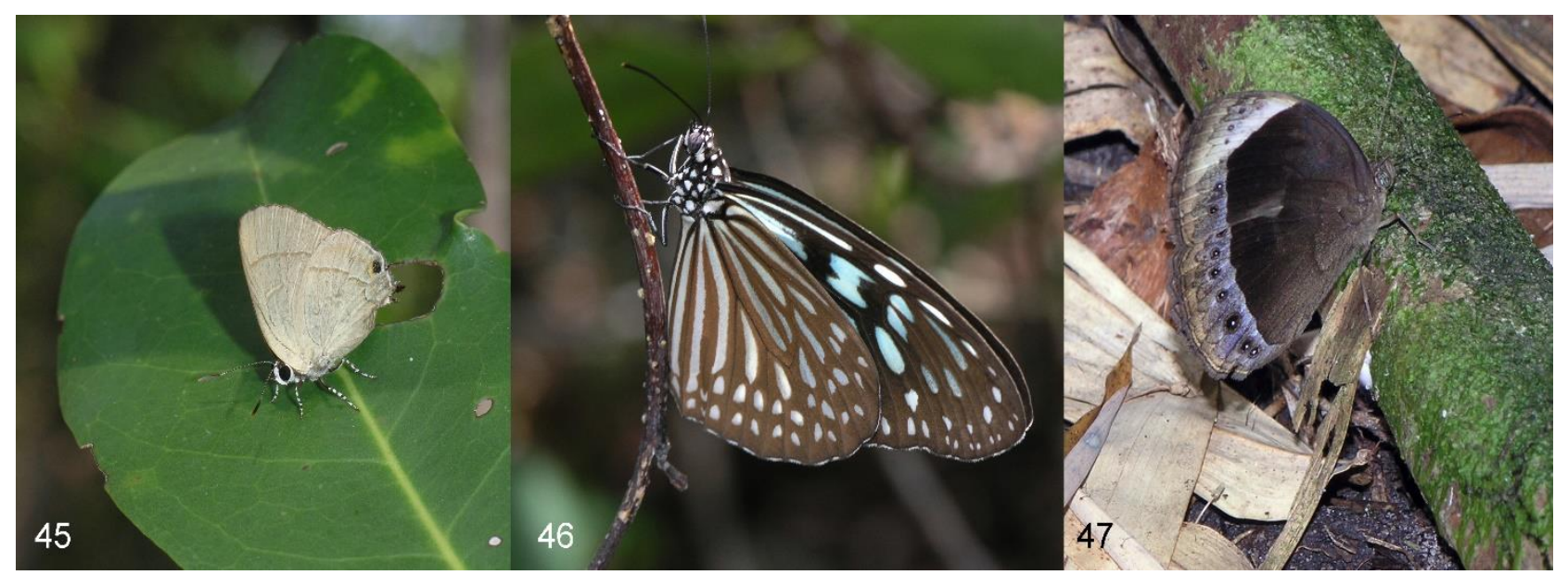

Figs. 45-47 Butterflies reported from Koh Kong Province in SW Cambodia, reidentified (45) or new for Cambodia (46-47), but not illustrated in the first communication of this series (Kosterin, 1919a): 45 - Rapala sp. cf. dieneces,, , 5\Koh Kong, NE suburbs, 14.04.2010; 46 - Ideopsis vulgaris contigua, 9 , 9\Boeng Kayak, 22.05.2013; 47 - Melanitis anaxioides, 12lGlaucum Brook, 28.11.2010. For explanation of localities, see Kosterin 1919a. Not to scale.

An oak blue individual photographed in Koh Kong Province at 63\Platystylus Brook, 20.08.2011 and identified as $A$. elopura in (Kosterin2019a: fig. 22) differs from the above presented individual of $A$. elopura (Fig. 11) in having a more pointed FW (because of male sex?), a somewhat darker UNS maculation and a differing mutual disposition of UNH spots in spaces 6 and 7: their outer margins in line with each other and with the inner margin of the spot in space 5; their inner margins not in line, that of the spot in space 6 overlapping with the cell end bar. In the here shown specimen from the Buu Sraa Waterfall (Fig. 11), both margins of the spot in space 7 are not in line with those of the spot in space 6, the inner border of which touching but not overlapping with the cell end bar. From the specimens presented by Inayoshi (2019) it seems that the mentioned differing characters are not reliable diagnostic. Although the specimen from Koh Kong Province is doubtful, I cannot suggest a better option than $A$. cf. elopura.

I did not notice that the reports from Koh Kong Province of a female of /deopsis vulgaris contiguaTalbot, 1939 ( $\$$, locality 9\Boeng Kayak, 22.05.2013) (Fig. 46) and Melanitis anaxioides Marshall et de Nicéville, 1883 (locality 12lGlaucum Brook, 28.11.2010) (Fig. 47) in Kosterin (2019a) were their first published records from Cambodia so did not mark and illustrate these species accordingly. To follow the principle of showing the first country records, I reproduce their photos herewith (Figs 46-47).

Also I had to mention that 31 of 47 species of butterflies, which I reported for Cambodia for the first time in literature, had been reported for Tatai Commune in Koh Kong Province of Cambodia by Gerard Chartier (2018) in internet, namely Graphium agetes agetes (Westwood, 1843), P. philomone clemanthe, Arhopala aida aida de Nicéville, 1889, Arhopala alitaeus mirabella Corbet, 1941, Arhopala atosia jahara Corbet, 1941, A. elopura, Cigaritis lohita himalayana (Moore, 1884), L. boeticus, Nacaduba pavana vajuva Fruhstorfer, 1916, Zizeera karsandra (Moore, 1865), Euploea phaenareta drucei Moore, 1883, Parantica agleoides agleoides (C. \& R. Felder), C. themire themire, Euthalia phemius phemius (Doubleday, [1848]), Discophora timora timora Westwood, [1850], Lethe mekara crijnana Fruhstorfer, 1911, Badamia exclamationis (Fabricius, 1775), Odina decorata (Hewitson,1867), A. nigrita maura, Erionota torus Evans, 1941, Gangara lebadea lebadea (Hewiston, 1868), Halpe zola Evans, 1937, Hiraotis adrastus praba (Moore, 1860), Lotongus calathus balta Evans, 1949, Matapa aria (Moore, 1866), Matapa sasivarna (Moore, 1866), Notocrypta clavata theba Evans, 1949, Polytremis lubricans lubricans(Herrich-Schaeffer, 1869), Pirdana hyela rudolphii Elwes \& d*e Nicéville, 1887, Suastus minutus aditia Evans, 1943, and Thoressa masoni (Moore, 1878).

\section{Discussion}

This paper reports, from 33 localities in the east of Cambodia as many as 118 identified and 5 provisionally identified species (in total 123), although this distinction is vague. As many as 19 species (Abisara cf. bifasciata, Poritia cf. hewitsoni, Ahmetia achaja, Arhopala nicevillei, Sinthusa chandrana, Virachola sp. cf. kessuma, Zizeera maha, Tirumala limniace, Junonia hierta, Yoma sabina, Terinos clarissa, Euripus nyctelius, Lethe rohria, Bibasis sena, Caprona agama, C. alida, Aeromachus cf. pygmaeus, Gangara thyrsis and Udaspes folus) and one distinct subspecies (Kallima inachus alboinachus) are reported for Cambodia in literature for the first time. Presence in Cambodia of seven of these species, namely $P$. 
hewitsoni, A. nicevillei, E. nyctelius, B. sena, C. agama, G. thyrsis and $U$. folus, has been already reported in Internet in the illustrated checklists of the fauna of Tatai Commune in Koh Kong Province by Gerard Chartier (2019a; 2019b), as well as U. folus also in my first communication of this series by visual observation (Kosterin, 1029a). U. folus and, especially, J. hierta are very common in Cambodia so absence of their records in literature was no doubt a matter of chance. $P$. hewitsoni, $A$. achaja, $A$. nicevillei. S, chandrana, C. alida and A. pygmaeuswere estimated by Ek-Amnuay (2006) as rare in the neighbouring Thailand. Of the entre here presented list of butterflies identified to species, at least provisionally, 83 were classified by the said author as common, 29 as medium abundant, 8 (the six above mentioned species plus $A$. bifasciata and $C$. nothis) as rare and 3 were not classified. As compared to 166 species reported from the coastal and low elevated SW provinces of Cambodia (Kosterin, 2019a), the here presented list of the more elevated eastern provinces is impoverished with representatives of the speciose genus Arhopala (3 versus 11 identified to species).

The richest places appeared to be the Yorn village environs (Loc. 73】) in Ratanakiri Province, with 31 identified species photographed for three days, and the Buu-Sraa Waterfal environs including the 'Loringae brook' (Locs. 951 and 961, respectively), with 28 species photographed for seven days of examination in total. One hour spent at the Ta Veang village environs (Loc. 721) provided as many as 9 species of danains because of Heliptropium sp. growing abundantly at the Se San left bank, which is a plant from which the danain males collect the precursor of their sex pheromones.

I have added a dynamic checklist of butterfly species currently recorded in Cambodia, both published and not (Kosterin 2019d), with misidentifications in its sources not being excluded, to my Internet page with currently 882 photographs (clickable thumbnails expanding to large photos with captions in English and Russian) of Cambodian butterflies (Kosterin 2019c). It counts 475 species of butterflies ad interim.

\section{Acknowledements}

The author is grateful to Gerard Chartier for the help in species identification. The work was partly supported by International Dragonfly Fund and Russian State Scientific Project 0324-2019-0041.

\section{References:}

Callaghan CJ. 2009. The Riodinid Butteflies of Vietnam (Lepidoptera). Journal of Lepidopterists' Society, $63(2), 61-82$.

Chartier G. 2018. Taxa - Gee's Nature Tours; [accessed 2019 Nov 1]. http://geenature.com/taxa/.

Chartier G. 2019a. True Butterflies (Papilionoidea) - Gee's Nature Tours; [accessed 2019 Nov 1]. https://geenature.com/checklists/true-butterflies/.

Chartier G. 2019b. Skipper Butterflies (Papilionoidea) - Gee's Nature Tours; [accessed 2019 Nov 1 ]. https://geenature.com/checklists/skippers/.

Corbet AS. 1941. A key to the Indo-Malayan species of Arhopala Boisduval (Lepidoptera: Lycaenidae). Proceedings of the Royal Entomological Society of London. Series B 10(9): 149-170.

Ek-Amnuay P. 2006. Butterflies of Thailand. Fascinating Insects, Vol. 2 (First Edition). Amarin Printing and Publishing, Bangkok, Thailand.

Ek-Amnuay P, Chiba H, Kimura K, Inayoshi Y, Saito K, Seki Y, Uemura Y. 2007. Corrigenda to "Butterflies of Thailand" EkAmnuay, 2006. Yadoriga 213: 2-20.

Evans WH. 1957. A revision of the Arhopala group of Oriental Lycaenidae (Lepidoptera: Rhopalocera). Bulletin of the British Museum (Natural History). Entomology 5(3): 85-144.

Giudici A. 2019. The Thailand Butterflies Species Gallery; [accessed 2019 Nov 1]. http://www.thaibutterflies.com/thailandbutterflies-species-gallery.

Inayoshi Y. 2019. A Check List of Butterflies in Indo-China, chiefly from Thailand, Laos and Vietnam; [accessed 2019 Nov 1 ]. http://yutaka.it-n.jp.

Kosterin OE. 2014. Odonata of the sourth-west and north-east of Cambodia as studied in early rainy season of 2013. International Dragonfly Fund Report 67: 1-94.

Kosterin OE. 2016. A survey of Odonata of Mondulkiri, the elevated eastern province of Cambodia, for ten days in June 2014. International Dragonfly Fund Repor 98: 1-85.

Kosterin OE. 2019a. Occasional photographic records of butterflies (Lepidoptera, Papilionoidea) in Cambodia. 1. The coastal Cardamom foothills (SW Cambodia), 2010-2018. Acta Biologica Sibirica 5(1): 84-105. doi: 10.14258/abs.v5.i1.5196

Kosterin OE. 2019b. Update of 2017-2018 to Odonata of Kampong Saom Peninsula, Cambodia. International Dragonfly Fund Report 129: 1-24.

Kosterin OE. 2019c. Lepidoptera from Cambodia; [accessed 2019 Nov 1]. http://pisum.bionet.nsc.ru/kosterin/exotic/cambodia.htm/.

Kosterin OE. 2019d. A dynamic checklist of butterfly species recorded in Cambodia compiled from published and unpublished sources; [accessed 2019 Nov]. http://pisum.bionet.nsc.ru/kosterin/exotic/cambutlist.htm/.

Monastyrskii AL, Yago M, Odagiri K. 2011. Butterfly assemblages (Lepidoptera, Papilionoidea) of the Cardamom Mountains, Southwest Cambodia. Cambodian Journal of Natural History 2011: 122-130. 
Nakamura N. 2014 Distribution of Kallima inachus (Doyere, [1840]) and related species (Lepidoptera, Nymphalidae) in Indochina and adjacent regions with status alteration of Kallima inachus alicia Joicey \& Talbot, 1921. Butterflies (Teinopalpus) 66: 22-39.

Onodera H. 2007. A trip for butterflies collecting in Cambodia (23 Sep.- 2 Oct.2006). Yadoriga 215: 17-36 (Japanese).

Onodera H. 2008. A trip for butterflies collecting in Cambodia (14 May -23 May.2007). Yuzuriha 39: 54-61 (Japanese).

Onodera H. 2009a. A trip for butterflies collecting in Cambodia (14 May - 23 May.2007). Yuzuriha 40: 62-68 (Japanese).

Onodera H. 2009b. Short trip in Laos for meeting butterflies. Butterflies (Teinopalpus) 53: 33-45 (Japanese).

Onodera H. 2015. New knowledge on the butterflies of Laos. Butterflies (Teinopalpus) 70: 39-41 (Japanese).

Seki Y, Takanami Y, Maruyama K. 1991. Butterflies of Borneo. Vol. 2. Lycaenidae, Hesperiidae. 113 pp., 69 pl.

Woodfield E, Murton R. 2006. Butterfly Field Guide Southwest Cambodia. Frontier-Cambodia.

\section{Citation:}

Kosterin OE. 2019. Occasional photographic records of butterflies (Lepidoptera, Hesperioidea and Papilionoidea) in Cambodia. 2. Ratanakiri and Mondulkiri Provinces of eastern Cambodia, 2013-2018. Acta Biologica Sibirica 5(4): 21-37.

Submitted: 15.10 .2019 . Accepted: 01.12.2019

cross ref $\underline{\text { http://dx.doi.org/10.14258/abs.v5.14.6816 }}$

(C) 2019 by the authors. Submitted for possible open access publication under the terms and conditions of the

Creative Commons Attribution (CC BY) license (http://creativecommons.org/licenses/by/4.0/). 